\title{
GENETIC ASPECTS OF HEREDITARY ARRHYTHMOGENIC SYNDROMES IN CHILDREN AND ADULTS
}

\author{
Vesna Miranović ${ }^{1}$ and Snežana Crnogorac ${ }^{2}$ \\ ${ }^{1}$ Department of Children's Diseases, Clinical Center of Montenegro, Faculty of Medicine, \\ University of Montenegro, Podgorica, Montenegro; ${ }^{2}$ Department of Gynecology and Obstetrics, \\ Clinical Center of Montenegro, Faculty of Medicine, University of Montenegro, Podgorica, Montenegro
}

\begin{abstract}
SUMMARY - Recent research has revealed the genetic etiology of a number of heart diseases that cause sudden cardiac death. Lethal channelopathies are of great importance among the genetically determined heart diseases. Their basic characteristics are unpredictable and deadly nature, autosomal dominant inheritance with variable expressivity and incomplete penetrance in structurally normal heart, and absence of morphological and histological clues that a standard autopsy can identify. Minimum screening of the relatives of sudden cardiac death victims involves taking medical history, physical examination, electrocardiography, echocardiography, and exercise testing. Total positivity of classic genetic tests is only $15 \%-25 \%$. Even the next generation sequencing technology does not provide a positive result of genetic testing in more than $35 \%$ of cases. Therefore, it is necessary to identify a larger number of genes the presence of which can lead to sudden cardiac death, to reduce the number of false positive results, and point to the importance of conducting genetic testing of young victims of sudden cardiac death. Until then, it is enough to preserve $5 \mathrm{~g}$ of fresh heart tissue of sudden cardiac death victims at a temperature of $-80{ }^{\circ} \mathrm{C}$. The material can be analyzed years later without losing its actuality because it contains information important for the next generation of the sudden cardiac death victim relatives.
\end{abstract}

Key words: Heart diseases; Death, sudden, cardiac; Autopsy; Echocardiography; Genetic testing; Highthroughput nucleotide sequencing

\section{Introduction}

When an elderly person has a cardiovascular disease, he/she is aware of the risk that the disease brings, including death. Even 10\%-32\% of adults die sudden$1 y^{1}$. When a newborn, infant, toddler, adolescent, or young adult dies from heart disease, then it is a tragedy for the victim and for the parents who find it difficult to accept the fact that their children are mortal. Recent research in the field of genetics has revealed the ge-

Correspondence to: Assoc. Prof. Vesna Miranovic, PhD, Faculty of Medicine, University of Montenegro. U1. Mila Radunovića A3/68, Podgorica, Montenegro

E-mail: vesmir@t-com.me

Received March 6, 2017, accepted October 19, 2017 netic etiology of a number of heart diseases that cause sudden cardiac death, which pose a serious dilemma because heritability of the underlying disease puts the surviving relatives at risk of sudden death and confers urgency of its timely identification in order to design preventive treatment ${ }^{2,3}$. Genetically determined heart diseases are responsible for more than $50 \%$ of sudden cardiac deaths in children ${ }^{4}$.

\section{Definition of Terms and Scope of the Problem}

In order to get better view and understanding of the problem of sudden death, it is necessary to follow the definitions of some terms that are in close connection with it. Sudden death (SD) is defined as an unex- 
pected natural death in apparently healthy individuals that takes place during the first hour after the onset of symptoms ${ }^{5}$. Sudden cardiac death (SCD) is defined as a witnessed, natural unexpected death from cardiac causes occurring within one hour after the onset of symptoms in a previously healthy person or an unwitnessed natural unexpected death of a person observed to be well within $24 \mathrm{~h}$ of being found dead ${ }^{6}$. Sudden unexpected death (SUD) is a non-traumatic death that occurs instantaneously or within 24 hours of the onset of acute symptoms or signs ${ }^{1}$. Sudden infant death syndrome (SIDS) is a category of children younger than 1 year, including $70 \%$ to $80 \%$ of SUD victims with no identifiable cause found on postmortem investigation ${ }^{7}$.

By analyzing the relatively small number of published studies that address the incidence of SCD of infants, children, adolescents and young adults, as well as according to many years of our experience as pediatric cardiologists, we can conclude that $\mathrm{SCD}$ is relatively uncommon, with an incidence of 1.3 to $8.5 \mathrm{per}$ 100000 patient-years ${ }^{4}$. A Danish study showed the incidence of SCD to be 2.8 per 100000 person-years in a population aged 1-35 years ${ }^{8}$. Croatian physicians published the results on SCD in sport active persons aged up to 35 years with the total incidence of $0.06 /$ 100000 per year'. It is obvious that the number of potential victims is not large, but the fact that the background of many of these deaths can be genetically conditioned by arrhythmogenic syndromes and that several other asymptomatic family members can be affected by the same disease, requires that SUD in patients younger than 35 years be carefully studied.

\section{Defining the Cause of Sudden Death}

The age of the victim largely indicates the cause of death. Ischemic heart disease is the leading cause of death in people older than 35 years, while the most common cause of death of people younger than 35 years is cardiomyopathy, followed by ischemic heart disease, valvular disease, and diseases of the conduction system of the heart ${ }^{10-14}$.

Lethal channelopathies are of great importance among the genetically determined heart diseases. Their basic characteristics are unpredictable and deadly nature, autosomal dominant inheritance with variable expressivity, incomplete penetrance in structurally nor- mal heart, and absence of morphological and histological clues that a standard autopsy can identify ${ }^{15,16}$. The pathophysiological mechanism that leads to a fatal outcome is electric dysfunction caused by genetic defects of the genes encoding the subunits of cardiac ion channels or regulatory proteins in ion channels of cardiac muscle cells. The most important among them are the long QT syndrome (LQTS), shortened QT interval syndrome (SQTS), catecholaminergic polymorphic ventricular tachycardia (CPVT), and Brugada syndrome $(\mathrm{BrS})$.

\section{Symptoms and Their Importance}

Numerous symptom diversities are most evident in the case of Brugada syndrome $(\mathrm{BrS})$. There is the greatest possible range of symptoms depending on penetrance and expressivity, from completely asymptomatic carriers with fully normal length of life and quality of life to a sudden death in the first year of life ${ }^{17}$. Typical for this syndrome is considered to be a situation where the victim of SD is a man aged about 40 who died in sleep ${ }^{18}$. The largest series of studied results of molecular autopsy showed that the largest number of SUD (33\%) occurred in dream or during exercise $^{19}$.

The existence of asymptomatic carriers of hereditary arrhythmogenic syndromes is of particular importance because medical history hides plenty of subtle, nonspecific symptoms expressed by a number of SD victims. Nonspecific symptoms, such as syncope, were present in a Swedish study of SCD victims from 15 to 35 years of age, which showed that $46 \%$ of SCD victims sought medical assistance due to the presence of symptoms before the tragic event ${ }^{20}$. Besides the fact that vaso-depressor syncope is not a predictive factor for $\mathrm{SD}$, it is possible to extract syncope that requires a more extensive evaluation looking for possible cardiac etiology $y^{21,22}$. The existence of warning signs was identified in half of the victims with channelopathies in personal or family history, citing as an example that 30\% of cases of SCD as a consequence of CPVT, family history contains information on one or more premature deaths by the age of $40^{19,23,24}$.

Cardiac arrest may be the first clinical manifestation in apparently healthy people, while the cardiac arrest interrupted by resuscitation measures occurs in $5 \%-10 \%$ of patients with LQTS ${ }^{25}$. Death is the first 
symptom of the disease in 30\% of cases with CPVT ${ }^{24}$. Pronounced penetrance of the pathogenic CPVT variant RyR2 has a mortality rate of $30 \%-50 \%$ by 35 years of life, resulting in a small number of asymptomatic carriers $^{26,27}$.

In addition to the corpus of common symptoms, each of hereditary arrhythmogenic syndromes has its own distinctive clinical characteristics. CPVT is typically manifested in effort syncope, syncope during emotional stress, or sudden death as a result of polymorphic ventricular tachycardia during childhood, adolescence or young adulthood. Heart rhythm disorder in LQTS can be caused by excessive physical activity, swimming, emotional stress, sound stimuli (e.g., alarm clock), etc.

\section{Recommended Diagnostics in SCD Victims and Their Relatives}

Of particular importance is the fact that it is difficult to determine the cause of death in infants and young adults undergoing autopsy with negative result. In these cases, it is deemed that death occurred due to hereditary arrhythmogenic syndromes in a structurally normal heart ${ }^{28}$. Under a structurally normal heart is deemed the heart without minimum macroscopic and microscopic deviations, including mild fatty infiltration of the right ventricle and slight myxomatous mitral valve ${ }^{19}$. It was concluded that arrhythmia caused death of $35 \%$ of autopsy-negative SD victims during the 25 years of studying the causes of SD in one US military base ${ }^{10}$.

When standard autopsy cannot determine the cause of death, other diagnostic possibilities are genetic testing of members of the victim's family and molecular autopsy. Testing of family members has a diagnostic, prognostic and therapeutic implications for relatives of those victims whose genetic tests are negative, and for those relatives of victims without clinical signs of disease whose genetic tests are positive ${ }^{29}$. Molecular autopsy is a process where DNA is extracted from the blood after death and then the selected genes responsible for major primary arrhythmogenic diseases are analyzed ${ }^{30}$. Diagnostic capacities of molecular autopsy can significantly influence prevention of SCD in the general population. The formation of multidisciplinary teams consisting of a pathologist, geneticist and cardiologist allows for more efficient transfer of information among health professionals in relation to the victim's family, thus increasing the coverage of families that participate in genetic counseling and cardiac treatment in order to identify asymptomatic carriers of hereditary arrhythmogenic syndromes ${ }^{31}$.

Geneticists are expected to provide genetic counseling of family members of SCD victims with detailed information on the risks, benefits and options available for clinical genetic testing. Clinical cardiac evaluation of SCD victim's relatives considers collecting data from personal and family medical history and clinical cardiologic examination, which is invaluable for diagnosis. The introduction of a minimum SCD screening for all relatives of the first order autopsynegative victim is proposed in some studies, including taking detailed personal and family history, physical examination, 12-channel electrocardiography (ECG), stress test, and echocardiography ${ }^{32}$. The same source suggests that an alternative or even simultaneous molecular autopsy for the major genes for LQTS, CPVT and $\mathrm{BrS}$ be done as part of standard procedure in the evaluation of autopsy-negative SUD victims younger than 40 years $^{33}$. Other sources pay special attention to detailed history data collected, which indicate the circumstances in which the death occurred and the age at which the victim $\operatorname{died}^{3}$. It is also recommended that 12-channel ECG recording at rest be made in the surviving relatives, as well as exercise testing and $2 \mathrm{D}$ echocardiography. Flecainide test is recommended when there is suspicion of $\mathrm{BrS}$. In the cited study, molecular genetic analysis was conducted on surviving relatives, but not molecular autopsy. Candidates for genetic analysis are selected on the basis of the results of clinical trials ${ }^{3}$.

Some studies suggest the use of a combined approach as a rational diagnostic variant. It implies that the SCD victim's family are informed on the suspected genetic background of SCD and the need for cardiac evaluation. At the same time, molecular analysis should be conducted in the SCD victim, as these results are better interpreted integrally with clinical assessment of the family members of SCD victims. In case of positive molecular autopsy, DNA screening can be extended to family members to identify carriers of the same mutation. The aim of the implementation of molecular autopsy is to increase the reliability of diagnosis and facilitate cascade screening of family members with a focus towards targeted testing ${ }^{34,35}$ 
Danish Statens Serum Institute and Department of Cardiovascular Diseases in Rijeka followed the integrated standard clinical approach and genetic analysis in all patients with clinical diagnosis of hereditary arrhythmogenic syndromes and their relatives. They proved that combined approach allowed better identification of patients at an increased risk of $\mathrm{SCD}^{36}$.

Plenty of good practice found in the literature still does not give a precise answer to the questions: which relatives should be treated cardiologically and which scope of other diagnostics to apply? In the search for answers to these questions, we should bear in mind the fact that over $95 \%$ of hereditary arrhythmogenic syndromes in the general population are inherited in the autosomal-dominant pattern, so that first-degree relatives have a one in two (50\%) chance of inheriting the gene mutation, and clinical evaluation of the first-order relatives is of utmost importance ${ }^{37,38}$. Results of clinical trials conducted in 2005 in young first-order relatives of SCD victims showed that $28 \%$ of them had heart channelopathies that could be identified ${ }^{38}$. More convincing are results of a study from 2008, which showed that the diagnosis of hereditary arrhythmogenic syndromes was detected in 53\% of first-order relatives of SCD victims after conducting a detailed cardiology examination ${ }^{39}$.

Clinical screening of SCD victim's family members is most successful if the existence of genetic mutations confirmed by molecular autopsy is detected in the SCD victim ${ }^{31}$. Molecular genetic analysis can be of great help to confirm the diagnosis in cases where there is not a striking enough phenotype ${ }^{40}$. However, the reliability of the clinical diagnosis is not in question when the result of the molecular genetic analysis is negative ${ }^{41}$

In order to assess the role and how to use genetic testing to identify hereditary arrhythmogenic syndromes, the European Heart Rhythm Association gathered a multidisciplinary team of experts who prepared the guidelines for the conditions in which genetic testing should be conducted ${ }^{30}$. The level of conflict in relation to the application of genetic testing is evident from the information that the experts themselves (who participated in drafting the guide) were not united and achieved consensus on all recommendations in $84 \%$ of cases, whereas on most they were consistent in $94 \%$ of cases $^{30}$.
Although the results of some studies have shown a particularly high level of positive molecular tests in SCD victims and their families, the real situation is far from satisfactory. The current generation of the LQTS mutation test gives positive result in $75 \%$ of the test and in less than $20 \%$ of SQTS cases $^{30}$. Total positivity of genetic testing is not more than $15 \%-25 \%{ }^{42}$. However, recent development of the next generation sequencing technologies (NGS) allows the analysis of a greater number of genes with reduced time and cost. The NGS technology rises the percentage of the potential pathogenic variants associated with arrhythmogenic syndromes leading to SCD to up to $35 \% \%^{43,44}$.

It is the obligation of medical professionals to provide the victim's family with answers (to the possible extent) to the questions of what led to death of their family member and whether any of the surviving relatives is a potential victim. The task of multidisciplinary teams is to minimize the risk of misinterpretation of autopsy findings, results of genetic tests and borderline results of cardiac tests ${ }^{44}$.

\section{Genetic Testing as Part of the Standard Diagnostic Procedure}

Identification of the people at risk of SCD is important because of the possibility of the application of preventive measures in the surviving family members of SCD victims. These are mostly channelopathies with structurally normal heart, which can be treated successfully, life can be extended, and better quality of life can be provided by using reliable prophylaxis (beta-blockers, sodium channel blockers in LQTS, implantable cardioverter defibrillator), which significantly lowers the risk of $\mathrm{SCD}^{45-48}$.

Despite the fact that DNA analysis of SCD victims opens new diagnostic features, it is still not part of the routine testing in any country of the world. In order to make genetic testing for hereditary arrhythmogenic syndromes part of the standard test procedures, it is necessary firstly to identify a much larger number of pathologic genes the presence of which can lead to $\mathrm{SCD}$. For now, only one gene unique to $\mathrm{BrS}$ is known and mutation can be identified in $30 \%$ of patients ${ }^{49}$. In addition, it is necessary to shorten the length of genetic testing to improve their practical value ${ }^{49}$. Also, it is necessary to reduce the number of 'unsafe' genetic screening which originates from identification of ge- 
netic variants that cannot be declared as pathogenic with great certainty. The term "variant of uncertain significance" refers to false-positive results of genetic tests, their percentage varying depending on the type of disease. For example, CPVT has a relatively low level of false-positive results of genetic testing, while there is an extremely high level of false-positive results of genetic testing for arrhythmogenic right ventricular cardiomyopathy, which is explained by the identification of rare, non-pathogenic mutations ${ }^{30}$. It is important to note that there is currently a struggle for supremacy among genetic testing laboratories over relevant intellectual property for heart rhythm disorder testing in order, they say, to produce more comprehensive and accurate test results ${ }^{50}$.

Financial aspect of the implementation of genetic testing is one of the challenges for their full integration into the standard package of tests. First, the concept and the contents of molecular autopsy is not fully defined, and it is not possible to determine the exact price of 'positive genotype ${ }^{\prime 4}$. It is difficult to justify the high cost of genetic testing since it is not directly intended to provide medical services and it is not used for treatment, as medical service is only evaluated in lay terms. Out of medical profession, it is not possible to justify the use of molecular autopsy in every SIDS since the test conducted on a sample of 200 SIDS victims showed mutations in the coding of ion channels typical of LQTS in $8.3 \%$ of cases $^{51}$. Some studies indicate that testing of the SIDS victims is positive for LQTS, CPVT and BrS together in only $10 \%-15 \%$ of cases $^{30}$. However, some health insurance systems have recognized the importance of NGS-based genetic tests to be eligible for coverage of hereditary disease. Reimbursement catalogue of the Germany statutory health insurance system that took effect July 1, 2016, classifies NGS genetic diagnostic tests for coverage requiring pre-authorization of tests analyzing more than 25 kilobases of $\mathrm{DNA}^{52}$.

The advantage of molecular autopsy over clinical evaluation of family members is not convincingly proven, and it is still easier to accept the necessity to make cardiologic testing in a large number of family members of SCD victims. Even the fact that $75 \%$ of patients with LQTS phenotype are carriers of specific genetic mutations with $45 \%$ diagnostic reliability in the case of negative family history and uncertain or borderline clinical signs is not persuasive yet ${ }^{53}$. While waiting for clarification of the basic dilemmas of the contents of diagnostic procedures and order of their application, as well as the completion of pathologic genes and reduction in the price of genetic tests, the option is available of simple sampling $5 \mathrm{~g}$ of fresh heart tissue or $10 \mathrm{~mL}$ of blood in EDTA SCD victim, and preserve it at a temperature of $-80{ }^{\circ} \mathrm{C}^{54}$. The human material thus obtained can be analyzed years after sampling without losing its relevance because it contains information of importance to the next generation of SCD victim's relatives.

Genetic testing in identification of the people at risk of SCD is important but still with many open questions. This diagnostic tool gives the possibility of applying preventive measures for surviving of SCD victim family members.

\section{References}

1. Oglesby P. On sudden death. Circulation. 1971;43:7-10.

2. Wilde AA, Tan HL. Inherited arrhythmia syndromes. Circulation. 2007;12:A12-9.

3. Tan H, Hofman N. Sudden unexplained death: heritability and diagnostic yield of cardiological and genetic examination in surviving relatives. Circulation. 2005;112:207-13.

4. Liberthson RR. Sudden death from cardiac causes in children and young adults. N Engl J Med. 1996;334(16):1039-44.

5. Pachon M, Almendral J. Sudden death: managing the patient who survives. Heart. 2011;97:1619-25, doi: 10.1136/hrt.2009.188375.

6. Myerburg R, Castellanos A. Cardiac arrest and sudden cardiac death. In: Brounwald E, editor. Heart Disease: A Textbook of Cardiovascular Medicine. Philadelphia: WB Saunders, 2001; p 890-931

7. Arnestad M, Vege A. Evaluation of diagnostic tools applied in the examination of sudden unexpected death in infancy and early childhood. Forensic Sci Int. 2002;125:262-8.

8. Marcus F, Chugh S. Unexplained sudden cardiac death: an opportunity to identify hereditary cardiac arrhythmias. Eur Heart J. 2011;32(8):931-3, doi: 10.1093/eurheartj/ehq505.

9. Sorić M, Mišigoj-Duraković M, Duraković Z. Exercise-related cardiovascular risks. Arh Hig Rada Toksikol. 2012;63(3): 95-102.

10. Eckart R, Scoville S. Sudden death in young adults: 25-year review of autopsies in military recruits. Ann Intern Med. 2004;141:829-34.

11. Chugh S, Reinier K, Teodorescu C. Epidemiology of sudden cardiac death: clinical and research implications. Progr Cardiovasc Dis. 2008;51(3):213-28, doi: 10.1016/j.pcad.2008.06.003 
12. Corrado D, Basso C, Thiene G. Sudden cardiac death in young people with apparently normal heart. Cardiovasc Res. 2001; 50(2):399-408.

13. Gallager P. The pathological investigation of sudden cardiac death. Curr Diagn Pathol. 2007;13(5):366-74.

14. Puranik R, Chow C, Duflou J, Kilborn M, McGuir M. Sudden death in the young. Heart Rhythm. 2005;2(12):1277-82.

15. Behr E, Wood DA, Wright M, Syrris P, Sheppard MN, Casey A, Davies MJ, McKenna W. Cardiological assessment of firstdegree relatives in sudden arrhythmic death syndrome. Lancet. 2003;362:1457-59.

16. Lee A, Ackerman MJ. Sudden unexplained death: evaluation of those left behind. Lancet. 2003;362:1429-31.

17. Brugada $\mathrm{P}$, Benito $\mathrm{B}$, Brugada $\mathrm{R}, \mathrm{Brugada}$ J. Brugada syndrome: update 2009. HJC Hellenic J Cardiol. 2009;50:352-72.

18. Shimizu W. Clinical impact of genetic studies in lethal inherited cardiac arrhythmias. Circ J. 2008;72:1926-36.

19. Tester DJ, Ackerman MJ. Postmortem long QT syndrome genetic testing for sudden unexplained death in the young. J Am Coll Cardiol. 2007;49:240-6.

20. Wisten A, Messner T. Symptoms preceding sudden cardiac death in the young are common but often misinterpreted. Scand Cardiovasc J. 2005;39(3):143-9.

21. Tretter JT, Kavey RE. Distinguishing cardiac syncope from vasovagal syncope in a referral population. J Pediatr. 2013; 163(6):1618-23, doi: 10.1016/j.jpeds.2013.07.023.

22. Adler A, Viskin S. Syncope in hereditary arrhythmogenic syndromes. Cardiol Clin. 2015;33(3):433-40, doi: 10.1016/j.ccl.2015.04.011.

23. Lahat H, Pras E. RYR2 and CASQ2 mutations in patients suffering from catecholaminergic polymorphic ventricular tachycardia. Circulation. 2003;107(3):29-30.

24. Priori SG, Napolitano C, Memmi M. Clinical and molecular characterization of patients with catecholaminergic polymorphic ventricular tachycardia. Circulation. 2002;106:69-74.

25. Goldenberg I, Zareba W. Long QT syndrome. Curr Probl Cardiol. 2008;33(11):629-94, doi: 10.1016/j.cpcardiol.2008.07.002.

26. Napolitano C, Priori SG, Bloise R. Catecholaminergic polymorphic ventricular tachycardia. In: Pagon RA, et al., editors. Gene Reviews. Seattle WA, 1993; p 856-64.

27. Puranik R, Chow CK, Duflou JA, Kilborn MJ, McGuire MA. Sudden death in the young. Heart Rhythm. 2005;2:1277-82.

28. Podrid P, Myerburg R. Epidemiology and stratification of risk for sudden cardiac death. Clin Cardiol. 2005;28:I-3-I-11.

29. Hofman N, Tan HL. Active cascade screening in primary inherited arrhythmia syndromes: does it lead to prophylactic treatment? J Am Coll Cardiol. 2010;55:2570-6, doi: 10.1016/j.jacc.2009.12.063.

30. Ackerman M, Priori S, Willems S, Berul C, Brugada R. HRS/ EHRA Expert Consensus Statement on the State of Genetic
Testing for the Channelopathies and Cardiomyopathies. Heart Rhythm. 2011;8(8):1308-39, doi: 10.1016/j.hrthm.2011.05.020.

31. Michaud J, Katarzyna M. Molecular autopsy in sudden cardiac death and its implication for families: discussion on the practical, legal and ethical aspects of the multidisciplinary collaboration. Schweiz Med Wochenschr. 2009;139:49-50, doi: smw-12837.

32. Tester DJ, Ackerman MJ. The role of molecular autopsy in unexplained sudden cardiac death. Curr Opin Cardiol. 2006; 21:166-72.

33. Nunn LM, Lambiase PD. Genetics and cardiovascular disease causes and prevention of unexpected sudden adult death: the role of SADS clinic. Heart. 2011;97:1122-7, doi: $10.1136 /$ hrt.2010.218511

34. Chugh SS, Kelly KL, Titus JL. Sudden cardiac death with apparently normal heart. Circulation. 2000;102:649-54.

35. Cerrone M, Priori SG. Genetics of sudden death: focus on inherited channelopathies. Eur Heart J. 2011;32:2109-18, doi: 10.1093/eurheartj/ehr082.

36. Brusić S, Hedley P, Čubranić Z, Benko K, Christiansen M. Genetic analysis of herditary heart diseases: the Danish-Croatian collaboration. Cardiol Croat. 2012;7(1):24.

37. Wilde AA, Behr ER. Genetic testing for inherited cardiac disease. Nat Rev Cardiol. 2013;10:571-83, doi: 10.1161/CIRCULATIONAHA.113.002252

38. Tan HL, Hofman N, van Langen IM, van der Wal AC, Wilde AA. Sudden unexplained death: heritability and diagnostic yield of cardiological and genetic examination in surviving relatives. Circulation. 2005;112:207-13.

39. Behr ER, Dalageorgou C, Christiansen M, Syrris P, Hughes S, Esteban MT. Sudden arrhythmic death syndrome: familial evaluation identifies inheritable heart disease in the majority of families. Eur Heart J. 2008;29:1670-80, doi: 10.1093/eurheartj/ehn219. Epub 2008 May 27.

40. Marcus F, Chugh S. Unexplained sudden cardiac death: an opportunity to identify hereditary cardiac arrhythmias. Eur Heart J. 2011;32:931-3, https://doi.org/10.1093/eurheartj/ehq428

41. Mazzanti A, Priori S. Molecular autopsy for sudden unexplained death? J Cardiovasc Electrophysiol. 2012;23(10): 1099-102, doi: 10.1111/j.1540-8167.2012.02430.x.

42. Crotti L, Arnestad M. The role of long QT syndrome in sudden infant death syndrome. Eur Heart J. 2005;26:127.

43. Campuzano O, Sanches M. Post-mortem genetic analysis in juvenile cases of sudden cardiac death. Forensic Sci Int. 2014; 245C:30-7, doi: 10.1007/s40279-017-0705-3.

44. Beckwith B. Defining the sudden infant death syndrome. Arch Pediatr Adolesc Med. 2003;157:286-90.

45. Villian E, Denjou I. Low incidence of cardiac events with betablocking therapy in children with long QT syndrome. Eur Heart J. 2004;25:1405-11.

46. Monning G, Kobe J. Implantable cardioverter-defibrillator therapy in patients with congenital long QT syndrome: a longterm follow-up. Heart Rhythm. 2005;2:497-504. 
47. Yanfei R, Liu N. Congenital long QT syndrome type 3. Cardiac Electrophysiol Clin. 2014;6(4):705-13, http://dx.doi.org/10.1016/j.ccep.2014.07.007.

48. Sroubek J, Buxton A. Primary Prevention Implantable Cardiac Defibrillator Trials: What Have We Learned? doi: http://dx.doi.org/10.1016/j.ccep.2017.08.006

49. Tan H, Bezzina C. Genetic control of sodium channel function. Cardiovasc Res. 2003;57:961-73.

50. 360Dx [dataset on the Internet]. Transgenomic Licenses Heart Rhythm Disorder Testing IP to LabCorp. GenomeWeb, New York. July 20, 2016. Available from: https://www.360dx.com/ molecular-diagnostics/transgenomic-licenses-heart-rhythmdisorder-testing-ip-labcorp?utm_source=TrendMD\&utm_ medium=TrendMD\&utm_campaign=1
51. Tester D, Ackerman M. Cardiomyopathic and channelopathic causes of sudden unexplained deaths in infants and children. Ann Rev Med. 2009;60(1):69-84.

52. $360 \mathrm{dx}$ [dataset on the Internet]. German Health Insurance A1lows Reimbursement of NGS Tests Up to Limit. GenomeWeb, New York. July 06, 2016. Available from: https://www.360dx. $\mathrm{com} /$ molecular-diagnostics/german-health-insurance-allowsreimbursement-ngs-tests-limit-excludes-cfdna?utm_source= TrendMD\&utm_medium=TrendMD\&utm_campaign=1

53. Basso C, Carturan E. Sudden cardiac death with normal heart: molecular autopsy. Cardiovasc Pathol. 2012;19:321-5, doi: 10.1016/j.carpath.2010.02.003.

54. Morrita H, Wu J. The QT syndromes: long and short. Lancet. 2008;372:750-63, doi: 10.1016/S0140-6736(08)61307-0

Sažetak

\section{GENETIČKI ASPEKTI IZNENADNE SMRTI KOD PRIROĐENIH ARITMOGENIH SINDROMA}

\section{Miranovići i S. Crnogorac}

Novija istraživanja na polju genetike su otkrila nasljednu etiologiju jednog broja srčanih bolesti koje izazivaju iznenadnu srčanu smrt. Smrtonosne kanalopatije su od velike važnosti među genetski uvjetovanim bolestima srca. Njihova temeljna obilježja su nepredvidiva i smrtonosna narav, autosomno dominantno nasljeđe s varijabilnom ekspresivnosti i nepotpunom penetrantnosti u strukturalno normalnom srcu u odsutnosti morfoloških i histoloških naznaka koje se mogu identificirati standardnom obdukcijom. Minimalni odabir srodnika žrtve iznenadne srčane smrti obuhvaća uzimanje anamnestičkih podataka, fizikalni pregled, kardiološki pregled, elektrokardiografiju, ehokardiografiju, test opterećenja. Ukupna pozitivnost klasičnih genetskih testova za otkrivanje urođenih bolesti srca je od 15\% do $25 \%$. Ni nova generacija tehnologije sekvenciranja ne nudi pozitivan rezultat genetskog testiranja u više od 35\% slučajeva, ni uz to što postupak testiranja traje kraće i jeftiniji je. Zato je potrebno identificirati veći broj gena prisustvo kojih može dovesti do iznenadne srčane smrti, smanjiti broj lažno pozitivnih rezultata genetskog testiranja, sigurnije ukazati na značenje provođenja genetskog testiranja mladih žrtava iznenadne srčane smrti, kako bi genetsko testiranje postalo dio standardnog dijagnostičkog postupka. Do tada je dovoljno uzeti i sačuvati $5 \mathrm{~g}$ svježeg srčanog tkiva žrtve iznenadne srčane smrti na temperaturi od $-80{ }^{\circ} \mathrm{C}$. Uzeti materijal može se analizirati i mnogo godina nakon uzimanja ne gubeći na aktualnosti, jer u sebi sadrži informaciju od važnosti za sljedeće generacije srodnika žrtve iznenadne srčane smrti.

Ključne riječi: Srčane bolesti; Smrt, iznenadna, srčana; Autopsija; Ehokardiografija; Genetsko testiranje; Visoki protok (propusnost) nukleotida, sinkroniziranje 